\title{
EFEKTIVITAS SISTEM LINGKUNGAN BAGI PENGEMBANGAN UMAT BERIMAN SESUAI KDPL KEUSKUPAN AGUNG SEMARANG
}

\author{
Andreas Budiyo
}

\begin{abstract}
:
This thesis examines the implementation of pastoral environments in Parish St. Peter and Paul, Babadan, Yogyakarta. And aims to look at the effectiveness of pastoral guidance for basic Christian's community (lingkungan) based on KDPL (Kebijakan Dasar tentang Pastoral Lingkungan) for the development of the faithful in the lingkungan. Basis of existing policies that would encourage the development of pastoral environment would boost the faith of the faithful. This thesis uses quantitative and qualitative methods. The Qualitative methods using means of questions aimed at people in the lingkungan of St. Peter and Paul Babadan Parish. Key informants are faithful in the lingkungan. While quantitative methods by asking for some leader of lingkungan and parish priest. Basic theory of the research policies is KDPL in the Archdiocese of Semarang. The data then analyzed and formulated as a conclusion.
\end{abstract}

Kata-Kata Kunci:

Lingkungan, Paguyuban, Umat Beriman Kristiani, Kebijakan Dasar tentang Pastoral Lingkungan.

\section{PENDAHULUAN}

\subsection{Latar Belakang Masalah}

Konsili Vatikan II melihat gambaran baru tentang Gereja sebagai persekutuan umat beriman yang percaya kepada Kristus. Gereja sebagai paguyuban berada di tengah perubahan masyarakat yang begitu cepat. ${ }^{1}$ Oleh karena Gereja sebagai sebuah kesatuan iman yang dibangun bersama-sama oleh seluruh umat beriman Katolik, maka kehidupan dan perkembangan Gereja Katolik menjadi tanggung jawab bersama. Gereja sedang menghadapi perubahan-perubahan pola tata sosial budaya agraris yang sedang berkembang menuju masyarakat modern. Pola kesatuan sebagai paguyuban umat beriman mendorong setiap orang untuk terlibat secara aktif dan mengambil peran mereka dalam menggembang-

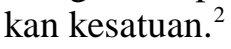

Gereja di Keuskupan Agung Semarang berkembang sebagai persekutuan dari paguyubanpaguyuban yang penuh pengharapan mewujudkan Kerajaan Allah. ${ }^{3}$ Partisipasi umat sangat diperlukan untuk mengembangkan berbagai aspek. Arah pastoral ini mendorong terbentuknya umat di wilayah. Wilayah-wilayah ini masih dibagi ke dalam lingkungan-lingkungan sehingga memungkinkan umat beriman memiliki tanggungjawab untuk terlibat aktif di sana. Paroki-paroki menggunakan sistem lingkungan untuk mewujudkan pelayanan yang efektif.

Penulis ingin meneliti apakah sistem lingkungan masih efektif di tengah umat yang berkembang cukup pesat terutama di wilayah paling dekat dengan Gereja pusat, jarak menengah (daerah kampung dan desa), jarak menengah (di daerah perumahan) dan wilayah paling jauh dengan Gereja pusat.

\subsection{Rumusan Masalah}

Ruang lingkup penelitian yang akan dilakukan yakni pengaruh pastoral lingkungan dalam pembangunan jemaat di Paroki Petrus dan Paulus Babadan. Untuk itu, pertanyaan penelitian yang ingin dijawab dalam penelitian ini yakni : Apakah sistem pastoral lingkungan di Paroki Petrus dan Paulus Babadan telah membantu perkembangan umat beriman? Apakah berbagai kegiatan baik 
intern maupun ekstern dalam lingkungan melambangkan keterlibatan Gereja bagi masyarakat?

\subsection{Batasan Penelitian}

Penelitian ini dilakukan di Paroki St. Petrus dan Paulus Babadan. Dalam hal ini yang menjadi informan utama serta responde yakni umat yang pernah menjabat sebagai ketua lingkungan atau pengurus lingkungan di dua lingkungan berbeda yakni daerah perumahan dan non-perumahan. Agar informasi lengkap maka data informasi diambil dari umat lingkungan yang bukan ketua atau pengurus lingkungan. Umat lingkungan tersebut merasakan sendiri efektivitas sistem lingkungan di daerah mereka.

\subsection{Metodologi Penelitian}

Metode penulisan tesis dan penelitian ini adalah dengan melakukan penelitian (kuantitatif). Metode ini dipilih dan dilakukan dengan menggunakan kombinasi metodologi: pertama, koesioner berupa pertanyaan terstruktur yang ditujukan kepada umat sebagai pengurus lingkungan melalui wawancara. Kedua, berupa pertanyaan terstruktur untuk umat di lingkungan perumahan dan non-perumahan di Paroki Babadan sebagai responden sekunder. Pertanyaan yang diajukan untuk mengevaluasi atau mengukur efektivitas kebijakan-kebijakan yang dibuat di lingkungan dalam membangun kesatuan umat terutama dengan situasi umat setempat. Di masing-masing lingkungan dipilih 5-10 responden. Sampel penelitian yang diambil pada umat dilakukan dengan pengambilan sampel acak sederhana (Simple Random Sampling).

Penelitian ini bertolak dari konsep, hipotesis, dan teori sistem lingkungan. Bagian penting dari penelitian ini yakni kelompok (lingkungan) sebagai unit analisisnya dan pengumpulan data dengan menggunakan koesioner (pertanyaan) yang terstruktur. ${ }^{4}$ Data yang diperoleh kemudian diklasifikasi dan dianalisa. Variabel yang digunakan yakni:

a) Variabel Kualitatif, untuk mengukur kemajuan reksa pastoral suatu paroki dalam mengembangkan kesatuan lingkungan-lingkungan.

b) Variabel Independen untuk melihat pengaruh sistem lingkungan yang berjalan saat ini bagi perkembangan umat beriman di lingkungan.

\section{HIDUP MENGGEREJA DALAM KOMUNITAS KECIL KRISTIANI}

Istilah komunitas kecil Kristiani yang dipakai dalam penjelasan ini diambil dari gagasan James O'Halloran dalam Signs of Hope: Developing Small Christian Communities. ${ }^{5}$ Penggunaan istilah ini menurut James dipengaruhi oleh karakter umat beriman dan situasi masyarakat yang ada dimana komunitas kecil Kristiani berkembang.

Komunitas kecil membawa harapan dan visi komunitas Kristiani sebagai bagian dari Gereja yang tidak dapat terpisah begitu saja dari pergumulan kehidupan umat manusia. Dinamika iman umat beriman Kristiani tampak nyata dalam komunitas-komunitas kecil yang bersentuhan langsung dengan realitas tersebut. Di sanalah, tampak communio Gereja umat Allah yang melibatkan diri dalam perjuangan Gereja dan masyarakat.

\subsection{Pengertian}

O’Halloran membagi tiga pengertian komunitas kecil Kristiani yang ada dalam perkembangan Gereja selama ini. Pengertian komunitas ini dilihat sejak awal perkembangan Kristianitas, Basic Ecclesial Communities (BEC), dan komunitas Gereja sebagai “sel”. Bentuk dan pengertian komunitas kecil terkait erat dengan situasi masyarakat dan dinamika hidup umat beriman di tengah dunia.

\subsubsection{Komunitas Kecil}

Bentuk awal gagasan komunitas kecil Kristiani menurut O’Halloran ialah persekutuan jemaatjemaat Kristiani dalam Perjanjian Baru. ${ }^{6}$ Mereka dipersatukan dalam iman akan Yesus Kristus yang bangkit dan hadir dalam seluruh jemaat. Mereka dipanggil dalam Roh Kudus dan berhimpun dalam perayaan Perjamuan Tuhan serta dalam pengajaran Para Rasul agar dengan santapan Tubuh dan Darah Tuhan seluruh persaudaraan mereka diteguhkan (lih. Kis 8:1; 14:22-23; 20:17). Meskipun kecil, "mereka menunjukkan lambang cintakasih dan kesatuan Tubuh Mistik dalam jemaat miskin atau terpencar, hadirlah Kristus (bdk. LG. 26).

Keuskupan Agung Semarang dalam Pedoman Dasar Dewan Paroki 2004 menggunakan istilah lingkungan yang dimengerti sebagai paguyuban orang-orang yang memiliki ciri-ciri di atas namun secara khusus berada dalam reksa pastoral suatu paroki. ${ }^{7}$ Selain di Keuskupan Agung Semarang, sebagian besar keuskupan di Indonesia mendefinisikan bahwa komunitas kecil mencakup baik teritorial maupun kategorial. ${ }^{8}$ Komunitas kecil dalam 
satu teritorial menunjuk pada suatu wilayah tertentu disebut lingkungan atau kring (Jawa dan beberapa daerah lain); Gabungan (daerah NTT, Ende). Sementara secara kategorial atau fungsional, komunitas kecil memiliki fungsi tertentu dalam Gereja.

\subsubsection{Base Ecclesial Communities (BEC)}

Gereja di Amerika Latin mengenal istilah komunitas kecil sebagai Comunidad Eclesial de Base (CEB). Istilah ini berasal dari bahasa Portugis yang diartikan sebagai komunitas Gerejawi dasar. Istilah CEB di Brasil kemudian diterima secara umum sebagai Base Ecclesial Communities $(B E C)^{9}$ atau Komunitas Gerejawi Dasar. Keberadaan komunitas kecil (BEC) ini merupakan realitas baru dalam hidup menggereja di Amerika Latin. BEC beranggota orang-orang miskin, tumbuh dimana Gereja belum hadir secara konsisten. Misalnya di daerah urban, pinggir kota, daerah-daerah pekerja atau buruh, dan daerah kelas menengah. Secara umum, komunitas BEC hadir di tengah situasi ekonomi dan sosial budaya masyarakat yang berada dalam situasi sulit.

Beberapa istilah yang sering dipakai di Indonesia antara lain: Komunitas Basis Gerejawi (KBG), Komunitas Katolik tingkat Basis (KKB), Komunitas Kristiani Kecil (Small Christian Communities), Komunitas Umat Basis (KUB) atau Komunitas Basis saja. ${ }^{10}$ Nama komunitas kecil ini memang berbeda tapi memiliki makna yang sama. Komunitas kecil sama-sama dimengerti sebagai "suatu persekutuan umat yang relatif kecil, saling mengenal, tinggal berdekatan, atau memiliki kepentingan bersama dan secara berkala mengadakan pertemuan. Mereka melakukan banyak kegiatan: berdoa, membaca, dan sharing Kitab Suci. Dari persekutuan itu mereka mengadakan kegiatan bersama dalam anggota dan masyarakat di sekitar mereka. Dan keberadaan mereka di bawah naungan Gereja Universal”. ${ }^{11}$

\subsubsection{Gereja "Sel”}

Umat beriman Kristiani membentuk komunitas kecil dan terlibat dalam kehidupan menggereja pada tingkat paling kecil. Mereka membentuk komunitas kecil dengan aneka latar belakang berbeda. O’Halloran mendefinisikannya dalam beberapa pengertian ${ }^{12}$ :

a) Komunitas kecil Kristiani ialah kelompok yang terdiri dari delapan sampai tiga puluh orang yang disatukan dalam suatu wilayah atau saling bertetangga. b) Komunitas kecil yang memiliki beberapa ciri :

- Berbagi iman yang sama yakni iman akan Yesus Kristus.

- Terikat akan Sabda Hidup (Dalam terang Sabda itu mereka mengatasi berbagai persoalan) dan menghidupi Sabda itu dalam hidup bersama.

- Mengusahakan pelayanan bagi sesama.

c) Kelompok umat beriman Kristiani yang memiliki ikatan mendalam satu sama lain dan memiliki kesatuan dengan Visi Gereja.

d) Kelompok yang secara alami memiliki karakter sebagai Gereja Universal yang didasari iman, cinta, perayaan, misi Gereja.

Dalam pengertian tersebut, komunitas kecil sebagai "sel” yang berkembang sebagai bagian Gereja Universal. Melalui mereka, Gereja semakin tampak nyata dan menampakkan identitas Kristus dalam kehidupan komunitas-komunitas tersebut.

Sinode Luar Biasa Para Uskup di Roma $1985^{13}$ menegaskan pentingnya keberadaan komunitas "sel" Gereja ini: Since the Church is a communion, the new "Basic Communities" as they are called are a true expression of communion, and an instrument for fashioning a more profound communion, provided they live in genuine unity with the Church. They are thus a sign of great hope in the life of the Church.

Komunitas kecil Kristiani ini hidup atas dasar iman akan Yesus Kristus serta tumbuh dan berkembang dalam Gereja. Di dalam pemahaman baru, himpunan umat beriman yang konkret itu berada dalam ruang dan waktu. $^{14}$ Dengan demikian, secara teritorial komunitas kecil Kristiani berada dalam paroki sementara paroki merupakan perwujudan Gereja setempat. Umat beriman dalam komunitas kecil Kristiani menghadirkan Gereja di tengah dunia.

\subsection{Tumbuhnya Komunitas-Komunitas Kecil dalam Gereja}

Dinamika pertumbuhan komunitas kecil terus berkembang dalam Gereja. Konsili Vatikan II telah membuka cakrawala baru akan hidup menggereja umat beriman sebagai komunitas iman. Gereja yang terdiri dari orang-orang yang dipersatukan dalam Kristus, dibimbing oleh Roh Kudus mencapai keselamatan. Gereja juga semakin terbuka untuk pengembangan communio umat beriman. Salah satu communio ini tampak dalam pertumbuhan komunitas-komunitas kecil dalam Gereja. 
Tumbuhnya komunitas-komunitas kecil dewasa ini menunjukkan bahwa pertumbuhan tersebut masih terus berlangsung hingga saat ini. Pengertian-pengertian tentang komunitas kecil telah dipaparkan pada bagian sebelumnya. Tumbuhnya komunitas-komunitas kecil Kristiani jaman modern ditandai dengan keberadaan komunitas pada pertengahan tahun 1950-an.

\subsubsection{Base Ecclesial Communities (BEC) di Brasil}

Komunitas kecil Kristiani telah berkembang sejak abad-abad awal Kristianitas. Di era modern, komunitas kecil berkembang di Brazil sekitar tahun 1950-an dengan istilah Base Ecclesial Communities (BEC). ${ }^{15}$ Komunitas kecil di sana terbentuk sebagai sebuah tanggapan atas keprihatinan dan keterlibatan umat di Brazil serta ketergantungan pada keberadaan imam. Menurut Leonardo Boff ${ }^{16}$ umat memiliki ketergantungan pada keberadaan seorang imam. Hal inilah yang mendorong Dom Agnello Rossi, membangun komunitas kecil pewartaan di Barra do Pirai, Brazil. Para Uskup juga memberi dukungan dalam pertemuan para Uskup Amerika Latin di Kolombia (1968) dan Mexico (1979). Boff menegaskan peran komunitas kecil tersebut:

Perhatian lebih spesifik bagi komunitaskomunitas kecil Kristiani ialah pembinaan gerakan komunitas “akar rumput” melalui bidang kateketik (pengajaran) dan pendidikan iman melalui pewartaan radio di Rio de Janeiro, Brazil serta karya apostolis kaum awam dalam paroki. Di dalam pelayanan itulah gambaran pembaharuan dari sebuah kerangka kerja pastoral dapat mulai direncanakan. ${ }^{17}$

Selain BEC di Brasil, perkembangan komunitas-komunitas Kristiani terjadi di Afrika, Asia (Philipina, Indonesia, Papua New Guinea dan Cina), Eropa dan Amerika Serikat. ${ }^{18}$ Gambaran perkembangan ini menunjukkan bahwa komunitas kecil Kristiani adalah sumber harapan bagi Gereja Universal. ${ }^{19}$ Komunitas-komunitas ini menjadi penggerak untuk mengembangkan berbagai aspek dalam komunitas yang lebih besar yakni Gereja.

\subsubsection{Small Ecclesial Communities (SEC) di Afrika}

Komunitas kecil Kristiani di Afrika tumbuh dan berkembang di tengah situasi sosial politik yang terus bergejolak. Situasi ini bahkan dapat digambarkan menyerupai perjuangan komunitas kecil Kristiani pada abad awal Kristianitas. ${ }^{20}$ Kualitas seorang Kristen teruji dalam pelayanan bagi sesama. Wilayah pastoral yang sulit dan kurangnya pelayan-pelayan menjadi faktor penghalang.

Perkembangan komunitas-komunitas kecil di Afrika amat ditopang oleh usaha pelatihan dan perencanaan bagai kaum awam. Di Afrika Utara saja ada sekitar 10.000 komunitas kecil tersebar di masing-masing paroki. Sementara di Afrika Selatan ada sepuluh komunitas di masing-masing paroki. ${ }^{21}$ SEC di Afrika berkembang dengan disertai usaha dialog yang terus menerus dengan budaya setempat yang beraneka ragam. Dialog ini justru semakin memperkaya cara pandang Gereja Afrika di tengah tantangan.

\subsubsection{Komunitas-Komunitas Kecil di Asia}

Gereja di Asia dalam dunia modern abad ke21 berhadapan dengan berbagai tantangan. Para Uskup Asia ${ }^{22}$ menyadari bahwa keberadaan komunitas kecil dalam jemaat di Asia memiliki kaitan yang erat dengan situasi pastoral saat ini. Situasi pastoral ini mendorong Gereja untuk melakukan perubahan yang tulus dan radikal mengenai sikap-sikap mental, struktur-struktur dan pelayanan-pelayanan jemaat Kristiani jaman sekarang. ${ }^{23}$

Gereja tidak dapat menunaikan misi pelayanan tanpa bersifat setempat (lokal). Gereja perlu terlibat dalam suatu bangsa dan kebudayaan yang terikat ruang dan waktu pula. Misteri Gereja ialah satu, bersifat total dan universal, namun diwujudkan secara konkret dalam bentuk berbeda-beda, anekaragam dan khusus. ${ }^{24}$ Persekutuan orangorang beriman berada pada komunitas paling kecil dalam Gereja dan berdasarkan citarasa saling bersatu dan saling memperdulikan dalam persaudaraan yang terbuka bagi semua orang. Gereja Asia memiliki kompleksitas kebudayaan, kepercayaan, agama dan realitas kemiskinan. Komunitas kecil di Asia pun terdorong untuk semakin membangun communio dalam semangat dialog yang tulus.

\subsection{Ciri-Ciri Komunitas Kecil Kristiani}

Pada bagian sebelumnya telah dipaparkan istilah-istilah komunitas kecil sebagai bentuk menggereja umat beriman. Pengertian ini didasarkan tempat dimana komunitas kecil terbentuk. Keberadaan dan proses perkembangan komunitas kecil pun memiliki beberapa ciri pokok, yakni :

\subsubsection{Komunitas Kecil Kristiani Sebagai Persekutuan (Communio)}

Communio berasal dari kata cum dan munus, yang berarti sama-sama memenuhi sebuah tugas. Dengan lebih sederhana, communio dapat dimen- 
gerti sebagai “dibagikan untuk semua”. Sementara dalam bahasa Latin Klasik, communio berarti berbagi, kepemilikan bersama sebagai masyarakat. ${ }^{25}$ Dalam Tradisi Patristik, istilah communio dipahami sebagai umat yang berasal dan bersumber pada Allah sendiri. Kesatuan tersebut akhirnya menghasilkan buah-buah rohani yang mengalir dari Ekaristi. Dalam pemecahan roti ekaristis, kita secara nyata ikut serta dalam Tubuh Tuhan; maka kita diangkat untuk bersatu dengan Dia dan bersatu antara kita. ${ }^{26}$

Kesatuan Allah dan manusia juga diungkapkan dalam Dei Verbum 2 dengan pengertian bahwa Allah selalu menyapa manusia dan memanggil manusia untuk masuk dalam persekutuan dengan-Nya. Konstitusi menyebut kesatuan inilah yang menjadi tujuan Allah bagi seluruh umat manusia:

Dalam kebaikan dan kebijaksanaan-Nya Allah berkenan mewahyukan diri-Nya dan memaklumkan rahasia kehendak-Nya (lih Ef 1:9); (lih Ef 2:18; 2 Ptr 1:4). (lih Kol 1:15; 1 Tim 1:17

Kesatuan manusia dengan Allah dalam communio menjadi kepenuhan martabat manusia. Dalam hal ini, Konstitusi Pastoral merumuskan bahwa dasar communio manusia yang paling utama yakni panggilannya untuk bersatu dengan Allah sendiri dengan pencipta-Nya (bdk. Gaudium et Spes 12). Dalam kesatuan itulah, manusia menunjukkan martabatnya yang luhur sebagai ciptaan Allah yang paling mulia. Communio manusia sebagai ciptaan menghadirkan keluhuran Allah sebagai Sang Pencipta.

\subsubsection{Komunitas Kecil Kristiani Berciri Communio Trinitas}

Komunitas kecil Kristiani sebagai sebuah kesatuan kelompok orang-orang yang oleh karena iman akan Yesus Kristus membangun kesatuan dan saling mengasihi satu sama lain. Dasar kesatuan untuk membangun komunitas kecil Kristiani adalah kasih yang dihidupi dan dibagikan dalam kesatuan. Yesus sendiri mengungkapkan doa kepada Bapa agar mereka semua orang bersatu. Kesatuan yang diharapkan Yesus dapat terwujud ialah kesatuan seperti Yesus dengan Bapa dalam Roh Kudus (lih. Yoh 17:20-21). Dasar harmoni dalam relasi Trinitas menjadi akar yang merangkum kesatuan umat beriman dengan Allah. ${ }^{27}$

Gereja umat Allah merupakan persekutuan (communio) yang "disatukan berdasarkan kesatuan Bapa dan Putera dan Roh Kudus”. ${ }^{28}$ Persekutuan dengan Allah Tritunggal itu bukan hanya me- rupakan sumber dan pola kesatuan Gereja tetapi juga sumber dan tujuan hidup seluruh umat manusia. Dalam terang paham ini, komunitas-komunitas kecil telah menandakan persekutuannya dengan Allah Tritunggal.

\subsubsection{Komunitas Kecil Kristiani Sebagai "Sel” Gereja}

Gereja tidak dapat dilepaskan dari keberadaan komunitas kecil sebagai bagian terkecil dari umat beriman. Mereka membentuk kesatuan dari berbagai latar belakang. Komunitas kecil Kristiani juga sering dimengerti sebagai "sel” terkecil Gereja yang terlibat dalam hidup masyarakat. Pertama, Komunitas kecil Kristiani dapat dimengerti sebagai kelompok yang terdiri dari delapan sampai tiga puluh orang yang tinggal di suatu wilayah tertentu atau bertetangga ${ }^{29}$. Keberadaan anggota ini didasari oleh beberapa kesamaan:

a. Masing-masing anggota berbagi iman akan Kristus sebagai Penebus.

b. Hidup dalam kesatuan Sabda dan menghidupinya sebagai komunitas.

c. Membangun semangat saling membantu terutama bagi mereka yang tersingkir.

Kedua, komunitas ini terdiri dari anggota yang memiliki ikatan mendalam satu sama lain dan memiliki visi Komunitas Gereja. Ketiga, komunitas ini telah memiliki karakter Gereja Universal yakni iman, harapan, cinta, ibadat, misi, pewartaan, pelayanan, dan kesatuan dengan imam.

Komunitas kecil sebagai sebuah "sel" dalam Gereja dijelaskan oleh seorang Kardinal Jerman, Silva Henriquez ${ }^{30}$ sebagai sebuah sketsa yang lengkap. Baginya, komunitas kecil memberi harapan dengan memberi pelayanan signifikan dalam Gereja Amerika Latin. Keberadaan komunitas kecil sekaligus mendorong terbentuknya komunitaskomunitas lain. Sebagai "sel” yang hidup dalam Gereja, komunitas kecil ini memberi kehangatan dimana Injil dapat dihidupi secara total. "Sel” kecil ini akan tumbuh berkembang menjadi paroki atau keuskupan dan sekaligus menjadi sarana penting bagi pewartaan di tengah dunia yang semakin materialistis.

Umat beriman Kristiani membentuk komunitas dalam bentuk yang paling kecil. Kaum awam dalam komunitas-komunitas menjadi "sel” paling nyata dalam kebersamaan dengan semua orang. Mereka menghadirkan Gereja secara nyata dalam dunia. 


\subsubsection{Komunitas Kecil Kristiani Mewujudkan Misi Kristus}

Yesus Kristus datang ke tengah dunia untuk menghadirkan Kerajaan Allah dalam seluruh hidup-Nya. Yesus Kristus menghadirkan Allah Bapa yang mengutus-Nya di dalam Roh Kudus. Yesus yang bangkit juga terus menerus hadir di tengah umat beriman yakni dalam Gereja. Umat yang beriman dan percaya kepada-Nya mengalami kehadiran-Nya sebagai “Sakramen” Allah.

Kerajaan Allah yang menjadi misi pewartaan Yesus Kristus hadir dalam Gereja sebagai komunitas jemaat Kristiani. Komunitas-komunitas Kristiani akhirnya menjadi tempat dan sarana dimana Kerajaan Allah dapat tumbuh berkembang melalui hidup komunitas Kristiani sebagai kesatuan dalam Gereja. Gereja menjadi sakramen keselamatan sejauh menghadirkan secara real Yesus Kristus. ${ }^{31}$ Komunitas kecil Kristiani sebagai "sel” dari Gereja memiliki tugas dan misi Yesus di dunia, menjadi sakramen keselamatan bagi semua orang.

\section{GAGASAN LINGKUNGAN DALAM KEUSKUPAN AGUNG SEMARANG}

Umat berkembang dalam kelompok-kelompok kecil tersebar di berbagai tempat. Mereka berkembang sebagai umat Allah sekaligus hadir dalam masyarakat dengan berbagai persoalannya. Untuk itu, Dewan Pastoral Keuskupan Agung Semarang merumuskan kebijakan-kebijakan bagi komunitas kecil (lingkungan) tersebut di tingkat keuskupan. Kebijakan-kebijakan inilah yang digunakan sebagai acuan dan tuntunan umat beriman dalam lingkungan-lingkungan.

\subsection{Sejarah Awal Lingkungan}

Para misionaris di Pulau Jawa memulai karya misi mereka di Pulau Jawa dengan membentuk stasi-stasi kecil. ${ }^{32}$ Mereka membuka stasi-stasi baru dan menghimpun umat beriman baru yang potensial. Setelah jumlah mereka yang tinggal di suatu tempat tertentu mencukupi, tempat itu dinyatakan sebagai stasi sendiri. Stasi yang telah memiliki jumlah yang cukup banyak, situasi strategis dan dapat ditempati seorang misionaris, maka stasi tersebut dinamakan "stasi induk".

Boelaars $^{33}$ menjelaskan lebih lanjut keberadaan umat katolik di daerah-daerah terpencil sejak semula menjadi perhatian para misionaris ${ }^{34}$. Mereka berhadapan dengan kendala pelayanan paling besar yakni situasi medan pelayanan. Sementara itu, umat Katolik sendiri selama 1970-an mengalami banyak tantangan dari pemerintah maupun umat beragama lain. Namun keberadaan umat Katolik di pelosok-pelosok tetap membangun kesatuan dengan mengatasi berbagai tantangan dari masyarakat.

Mgr. Soegijapranata SJ memulai ide tentang lingkungan saat ia mendapat tugas sebagai pastor pembantu di Paroki Bintaran dan Ganjuran. ${ }^{35}$ Di kedua paroki itu, ia mencetuskan ide dasar tentang lingkungan ${ }^{36}$ sebagai sebuah bentuk persatuan umat Katolik dalam suatu paroki.

Usaha-usaha sederhana yang dilakukan untuk mengembangkan lingkungan berupa : doa bersama, merayakan pesta-pesta Negara dan Gereja. Lingkungan terbentuk dengan didasari semangat Injil dan tumbuh dalam dinamika yang muncul dengan sendirinya dari, oleh dan untuk umat Katolik.

\subsection{Kebijakan-kebijakan Dasar tentang Pastoral Lingkungan (KDPL)}

Gereja Keuskupan Agung Semarang tahun 1990-1991 ingin menentukan kembali arah dasar bagi kehidupan umat beriman khususnya di Wilayah Jawa Tengah dan Yogyakarta. Tuntunan utama musyawarah tersebut tertuang pada Arah Dasar Keuskupan Agung Semarang 1990-1995 yakni hasil Musyawarah Kerja Keuskupan Agung Semarang terumuskan dalam bentuk Kebijakankebijakan Dasar Keuskupan Agung Semarang tentang Pastoral Lingkungan (KDPL). Kebijakankebijakan tersebut digunakan sebagai tuntunan bagi masing-masing lingkungan untuk mengembangkan diri dalam berbagai dimensi hidup bersama. ${ }^{37}$

Lingkungan merupakan bagian paling nyata dari kehadiran Gereja sebagai persekutuan umat beriman kepada Yesus Kristus. Lingkungan dijiwai oleh semangat persaudaraan dan menghidupi semangat Injil serta melibatkan diri dalam masyarakat. Dengan demikian lingkungan berada pada posisi yang secara langsung memberi kesaksian tentang Injil Yesus Kristus. ${ }^{38}$

Gagasan pastoral lingkungan dalam Kebijakan-kebijakan Dasar tentang Pastoral Lingkungan terdorong oleh panggilan Gereja sebagai tanda (sakramen) yang menyatakan kehendak Allah agar semua orang memperoleh keselamatan. Allah berkehendak membangun kerajaan damai di dunia untuk menghantar setiap orang sampai pada kepenuhannya di akhir zaman.

Kebijakan-kebijakan Dasar Keuskupan Agung Semarang tentang pastoral Lingkungan tersebut meliputi 5 pokok persoalan utama, yaitu: 

a. Jati Diri Kristiani
b. Persekutuan Iman dan Cinta Kasih
c. Pewartaan Kristiani
d. Kehidupan Beragama
e. Partisipasi dalam Pembangunan Masyarakat.

Mari kita lihat kelima pokok di atas secara lebih dekat.

\subsubsection{Pemahaman Dasar Jati Diri Kristiani}

Keberadaan dan jati diri Gereja mengalir dari panggilan dan pilihan Allah serta tanggapan manusia. Inisiatif pertama datang dari Allah dalam communio Tritunggal mewahyukan diri-Nya dalam Yesus Kristus bersama Roh Kudus. Jati diri umat beriman Kristiani melalui Gereja bersumber dari solidaritas Allah dalam Yesus Kristus dengan kehidupan manusia. Nilai-nilai Kristiani hidup secara nyata dalam diri seluruh umat beriman Kristiani di tengah kehidupan masyarakat dan dunia.

Penegasan jati diri Kristiani memiliki dasar jelas dalam Konstitusi Dogmatis Lumen Gentium dimana setiap umat beriman berada dalam kesatuan dengan seluruh Gereja sebagai “persekutuan orang-orang yang dipersatukan dalam Kristus, dibimbing oleh Roh Kudus dalam peziarahan menuju Bapa serta telah menerima warta keselamatan untuk diwartakan kepada semua orang” (bdk Lumen Gentium art 1).

Umat beriman Kristiani Keuskupan Agung Semarang hidup di tengah situasi sosial ekonomi masyarakat yang terus berkembang. Kemiskinan menjadi tantangan umat beriman Kristiani KAS dan bahkan masyarakat Asia. Gereja sebagai paguyuban sekaligus terbuka dan siap sedia menjalin kerja sama dengan siapa pun yang berkehendak baik untuk memperjuangkan kehidupan yang lebih adil, merdeka, dan manusiawi. Roh Kudus-lah yang mendasari perjuangan umat beriman sehingga berbagai usaha membawa daya tranformatif bagi tatanan hidup yang lebih adil dan penuh belas kasih demi persaudaraan. Daya transformatif dalam komunitas menjadi tanda paling jelas jati diri umat beriman Kristiani melalui pelayanan dalam lingkungan dan di tengah masyarakat.

Gereja Keuskupan Agung Semarang merumuskan tugas pendampingan lingkungan dalam Kebijakan-kebijakan Dasar tentang Pastoral Lingkungan sebagai berikut, "Untuk mengembangkan jati diri Kristiani umat di lingkungan beserta semua anggotanya, hendaknya kegiatan-kegiatan yang diselenggarakan demi pembinaan umat direfleksikan secara teratur. Proses pengembangan kegiatan-kegiatan itu hendaknya disertai pendampingan yang memadai”. ${ }^{39}$ Keterlibatan lingkungan dalam membangun pendampingan bagi seluruh umat sejalan dengan tegas mengambil pelayanan terhadap orang miskin, kecil, lemah dan terlantar sebagai alamat dari kegiatan patoralnya.

Keluhuran panggilan hidup manusia yakni bahwa setiap orang dihantar pada kepenuhan kepribadiannya. Dalam perwujudan kepenuhan pribadi setiap orang inilah, Gereja terpanggil dalam mengembangkan setiap manusia melalui kerja sama dengan semua orang untuk memperjuangkan kesejahteraan umum dan pembentukan dunia yang semakin manusiawi (bdk. Gaudium et Spes 3). Panggilan Gereja bagi kesejahteraan semua orang menjadi tanda jelas Gereja sebagai ragi atau jiwa bagi masyarakat (bdk. Gaudium et Spes 40).

\subsubsection{Lingkungan Membangun Persekutuan Iman dan Cinta Kasih}

Gereja Keuskupan Agung Semarang dalam Kebijakan-kebijakan Dasar tentang Pastoral Lingkungan merumuskan dua dasar utama dalam membangun kesatuan lingkungan yakni dasar iman dan cinta kasih dimana masing-masing anggota lingkungan dapat saling mengembangkan diri sebagai bagian dari masyarakat.

Kebiasaan membangun persekutuan sebagai umat beriman sebenarnya telah dikembangkan oleh para guru lulusan sekolah van Lith $^{40}$ sebagai cikal bakal pewarta iman Katolik di Keuskupan Agung Semarang. Gerakan umat beriman dalam kesatuan iman dan cinta kasih di dalam lingkungan selalu berupaya menangkap kehendak Allah dalam konteks zaman.

Lingkungan diharapkan meningkatkan struktur dan sistem kerja yang ada agar setiap anggota lingkungan dapat terlibat secara aktif dan penuh tanggung jawab ikut serta dalam kehidupan bersama (bdk. KDPL II, 2.2, 3). Bahkan keterlibatan setiap anggota lingkungan diharapkan tetap dapat dilakukan secara pribadi dengan mencari kesempatan untuk berkarya melayani sesama dan berbakti kepada masyarakat (bdk. KDPL II, 2.2, 4). Dengan demikian, baik dalam paguyuban sebagai lingkungan maupun perorangan, setiap umat beriman Kristiani dalam lingkungan terdorong untuk terlibat dan menanggapi keprihatinan masyarakat.

Solidaritas yang ingin dibangun oleh umat Keuskupan Agung Semarang berdasar pada 
pandangan solidaritas dalam dokumen Gaudium et Spes 1 (GS1). Perhatian Gereja terarah pada mereka yang mengalami kemiskinan dan keterbelakangan. Karena itu, kemiskinan dan keterbelakangan ini selalu menjadi pengerak bersama sebagai keuskupan. Lingkunganlingkungan menghadirkan diri dalam berbagai bentuk karya pelayanan.

\subsubsection{Pewartaan Kristiani}

Tugas pewartaan Kristiani dihidupi dalam arah dasar Keuskupan Agung Semarang yang bercita-cita untuk semakin mengikuti Yesus Kristus secara penuh dalam menjawab dan memaklumkan kabar gembira penyelamatan-Nya (bdk. Arah Dasar KAS). Cita-cita tersebut diwujudkan dalam langkah-langkah dan tindakan bersama semua orang yang kehendak baik. Gereja Keuskupan Agung Semarang ingin berkembang menjadi Gereja yang terbuka, serta memiliki kepedulian terhadap masalah-masalah yang dihadapi oleh masyarakat.

Tugas pewartaan umat beriman dalam lingkungan berakar dalam Kitab Suci. (bdk. Mat 28:16-20). Setiap orang beriman mendapat tugas yang sama untuk melanjutkan tugas pewartaan karya keselamatan Allah. Mereka diutus untuk menjalankan tugas misioner sebagaimana dikerjakan oleh Yesus sendiri. Tugas pewartaan setiap orang beriman Kristiani bersumber juga pada misi Gereja sebagai umat Allah yang menerima misi Tuhan sebagai perutusan mereka. ${ }^{41}$ Gereja di Asia kedati pada umumnya secara numerik marginal atau tersingkirkan, namun Gereja khususnya di Indonesia mampu menampilkan kehadirannya yang signifikan. ${ }^{42}$ Justru dalam situasi ini, tugas pewartaan semakin jelas dan nyata dalam penegasan solidaritas pada mereka yang tersingkir dari masyarakat.

Lingkungan tumbuh dalam pewartaan Injil Yesus Kristus melalui tugas dan pelayanan. Oleh karena itu, lingkungan membutuhkan pewartapewarta. ${ }^{43}$ Mereka secara bersama-sama maupun pribadi mengembangkan diri dalam berbagai ketrampilan dan kemampuan demi pelayanan.

\subsubsection{Kehidupan Beragama}

Kehidupan masyarakat Asia dan khususnya di Indonesia diwarnai oleh pluralitas religius. Kehidupan beragama bagi mayarakat Indonesia terungkap dalam berbagai macam keyakinan dan agama. Salah satu penegasan Kebijakan-kebijakan Dasar tentang Pastoral Lingkungan tentang kehidupan umat Kristiani dengan umat beragama lain, "Hendaknya jemaat lingkungan dalam cinta kasih Kristiani memandang umat yang berbeda agama dan kepercayaan sebagai rekan seziarah menuju Kerajaan Allah, sesama pengemban nilainilai manusiawi yang luhur serta teman untuk menyuarakan hati nurani yang lurus di tengah masyarakat”. ${ }^{44}$

Umat beriman Kristiani dalam kesatuan dengan cara pandang Gereja menyambut berbagai adat kebiasaan para bangsa, dalam keadaan baik dan utuh (bdk. Sacrosantctum Concilium 37). Umat beriman secara khusus dalam lingkungan, dapat terlibat aktif membangun persaudaraan tersebut melalui sikap dan semangat ini.

Langkah paling jelas yakni dengan menjumpai adat istiadat rakyat berupa warisan leluhur, tanahladang dan kebudayaan mereka sendiri. ${ }^{45}$ Perjumpaan umat beriman Kristiani dengan umat beragama lain juga meliputi semua kebiasaan-kebiasaan, perilaku, aturan-aturan, berbagai wujud gagasan budaya (nilai-nilai budaya, tolok ukur, aturanaturan yang saling berhubungan menjadi sebuah sistem). ${ }^{46}$

Munculnya keberagaman budaya dan adat istiadat memang diakui Gereja bersumber pada hakikat akan budi manusia (bdk.Gaudium et Spes 59). Keberagaman adat istiadat inipun diyakini sebagai pusaka warisan suku bangsa, ragam rukun hidup dan golongan-golongan yang ada dalam masyarakat. Ini berarti Gereja pun turut mengembangkan proses pemahaman terhadap aneka budaya dan adat istiadat.

Kebijakan-kebijakan Dasar tentang Pastoral Lingkungan merumuskan sebagai berikut: "Dalam suasana 'dialog kehidupan' itu hendaknya diusahakan pula 'dialog karya', yakni solidaritas dan kerja sama sebagai saudara semasyarakat, untuk memajukan nilai-nilai kesusilaan, keadilan sosial, perdamaian dan kebebasan bagi semua orang, yang harus mendasari hidup bermasyarakat dan berbangsa". ${ }^{47}$ Dialog karya merupakan perwujudan konkrit dari solidaritas dan kerja sama antar warga masyarakat dalam memajukan nilai keadilan sosial, perdamaian dan kebebasan bagi semua orang. Dialog karya menunjukkan sebuah usaha nyata dalam memecahkan persoalan-persoalan yang muncul dalam masyarakat.

Lingkungan hadir sebagai rekan seperjalanan dengan sesama bangsa Asia menuju kepenuhan Kerajaan Allah. Lingkungan didorong untuk mengembangkan persekutuan paguyuban-paguyuban bukan lagi sebagai paguyuban yang eksklusif namun tumbuh sebagai paguyuban yang terbuka dalam solidaritas dan kerjasama. Bidang-bidang 
kehidupan dalam masyarakat memberi kesempatan umat lingkungan untuk membangun jejaring dan kerja sama dengan mereka yang berkehendak baik.

\subsubsection{Partisipasi dalam Pembangunan Masyarakat}

Gereja hadir di tengah masyarakat dan melibatkan diri dalam berbagai usaha untuk memajukan kehidupan bersama. Untuk itu, perlu ditumbuhkan semangat partisipasi dalam pembangunan masyarakat. Beberapa bentuk partisipasi dalam pembangunan masyarakat diwujukan melalui penjelasan berikut ini.

Kebijakan Dasar tentang Pastoral Lingkungan merumuskan perhatian sosial dalam lingkungan sebagai berikut, "hendaknya dimensi sosial pewartaan Kristiani mendapat tekanan yang sewajarnya dan Ajaran Sosial Gereja diperkenalkan sebagai layaknya. Gereja juga berhadapan dengan masalah kesejahteraan dalam masyarakat. Lingkungan dapat memulai karya sosial ini melalui pembangunan sarana kesehatan, pendidikan, dan jaminan pekerjaan. Lingkungan didorong untuk memberi ruang dan kesempatan bagi semua anggota dan masyarakat agar semua orang mencapai kesejahteraan bersama.

Dijelaskan pula dalam KDPL bahwa "diperlukan upaya-upaya untuk menggali daya kemampuan lingkungan guna memperbaiki mutu kehidupan umum. Kesejahteraan umum tidak tercapai tanpa perjuangan bersama dengan kaum miskin dan terlantar". ${ }^{48}$ Masing-masing lingkungan tentu memiliki karakter dan kemampuan dalam mengembangkan umat.

Lingkungan didorong untuk membangun "Etos Kerja" yang mampu meningkatkan mutu hidup umat beriman dan semua orang. Kebijakan Dasar Keuskupan Agung Semarang tentang lingkungan mendorong "agar usaha menanamkan dan meningkatkan 'Etos Kerja' itu dimulai sejak ini dengan pendiikan dalam lingkungan keluarga". ${ }^{49}$ Lingkungan sebagai komunitas terkecil dapat pula mengusahakan upaya-upaya pemberdayaan dan solidaritas, yang khas lingkungan itu.

\section{HASIL PENELITIAN PENGARUH PASTORAL LINGKUNGAN DI PAROKI ST. PETRUS DAN PAULUS BABADAN}

Pada bab IV ini akan dipaparkan hasil penelitian Pengaruh Kebijakan Dasar tentang Pastoral Lingkungan (KDPL) Keuskupan Agung
Semarang bagi lingkungan-lingkungan di Paroki St. Petrus dan Paulus Babadan. Kebijakan Dasar ini telah ditetapkan sejak tahun 1991 di semua paroki tentang lingkungan. Kehadiran dan kehidupan umat beriman dalam lingkungan mengambil bagian penting dalam menunjukkan jati diri dan panggilan Gereja dalam masyarakat.

\subsection{Sampel dan Metode Penelitian}

Penelitian ini membahas tentang pengaruh sistem pastoral lingkungan sesuai Kebijakan Dasar tentang Pastoral Lingkungan di Keuskupan Agung Semarang. Penelitian dilakukan di 12 lingkungan dari keseluruhan 25 lingkungan yang ada di Paroki St. Petrus dan Paulus Babadan. Waktu pelaksanaan penelitian yakni antara bulan Oktober s.d November 2013. Menurut sensus umat tahun 2012, umat Paroki St. Petrus dan Paulus Babadan berjumlah 2.376 jiwa. ${ }^{50}$ Kriteria responden adalah umat yang tinggal di lingkungan-lingkungan dengan karakter berbeda.

Responden yang diteliti berusia 30 s.d 70 tahun. Responden tinggal di lingkungan-lingkungan. Pemilihan 12 lingkungan didasarkan pada perbedaan karakter lingkungan di 6 wilayah berbeda. Karakter lingkungan sebagai responden tersebut yakni:

a. Lingkungan yang paling jauh dari Gereja Pusat. Lingkungan-lingkungan tersebut letaknya 15-20 km dari Gereja Paroki Babadan. Meski tinggal jauh dari Gereja pusat, namun mereka memiliki kedekatan antar anggota atau keluarga. Lingkunganlingkungan meliputi lingkungan Sbastianus, Stefanus, Martinus. Lingkungan tersebut berada di satu wilayah dan memiliki satu kapel yakni Kapel Stasi St. Fransiskus Xaverius Cangkringan. Mereka terdiri dari keluarga-keluarga yang tinggal berjauhan dan rata-rata berusia 40-85 thn. Mereka tinggal berjauhan satu sama lain yakni di daerah lereng Gunung Merapi namun terlibat dalam kegiatan-kegiatan dalam lingkungan. Jenis pekerjaan responden yang tinggal di lingkungan tersebut yakni petani, buruh, dan guru.

b. Lingkungan-lingkungan jarak menengah yakni \pm 5-10 km, tinggal di daerah desa /kampung sekitar Gereja pusat (perumahan biasa). Mereka terdiri dari Lingkungan Stefanus Martir, Yohanes, Agustinus Hypo. Keluarga yang tinggal di lingkungan ini sebagian besar di rumah-rumah biasa (nonperumahan) dan tinggal dengan umat beragama lain di tiga atau empat desa 
berbeda. Jenis pekerjaan bervariasi : petani, buruh, karyawan, guru, dan wiraswasta. Kegiatan-kegiatan lingkungan berjalan karena didukung oleh keterlibatan kaum muda yang ada di lingkungan tersebut. Tingkat pendidikan bervariasi dari SD sampai Sarjana-diploma.

c. Lingkungan-lingkungan jarak menengah yakni \pm 5-10 km dan tinggal di daerah perumahan-perumahan sekitar Gereja pusat (daerah perumahan). Lingkungan-lingkungan tersebut meliputi Lingkungan Petrus, Lingkungan Ignatius, Lingkungan Skolastika, Lingkungan Yustinus. Lingkungan ini berada di empat kompleks perumahan yang ada di Paroki Babadan dan cenderung mengelompok dalam blok-blok berdekatan. Keluarga-keluarga di daerah ini memiliki dinamika hidup dan jenis pekerjaan sebagai dosen (guru), pengusaha dan karyawan suatu instansi. Dengan melihat jenis pekerjaan, dapat dilihat tingkat pendidikan mereka mulai dari Sarjanadiploma sampai S2-Doktor. Mereka yang tinggal di daerah ini memiliki tingkat ekonomi menengah ke atas.

d. Lingkungan-lingkungan paling dekat yakni \pm 1-2 km dengan Gereja pusat (dekat tapi “jauh”). Lingkungan tersebut yakni Lingkungan Antonius dan lingkungan Sisilia. Lingkungan-lingkungan ini memiliki dinamika hidup bervariasi dan tinggal di perumahan dan rumah biasa. Meskipun keluarga-keluarga tinggal berdekatan, namun kegiatan-kegiatan lingkungan terbatas pada rutinitas (doa mingguan). Selain itu, hubungan antar anggota lingkungan hanya terbatas pada kegiatan-kegiatan formalitas. $^{51}$ Tingkat keterlibatan lingkungan dalam kegiatan Gereja dan masyarakat masih belum maksimal. Pengurus lingkungan yang ada terdiri dari kelompok berusia 50-70 tahun.

Jumlah responden yang diwancarai tinggal di 12 lingkungan dari 24 lingkungan yang ada yakni berjumlah 121 orang. Lingkungan-lingkungan di Paroki St. Petrus dan Paulus Babadan tersebar di 6 wilayah. Jumlah responden tersebut diambil dari masing-masing kepala keluarga (KK) atau mereka yang mewakili setiap keluarga dalam lingkungan tersebut. Jumlah yang diambil diharapakan mampu mewakili seluruh umat yang ada di lingkungan-lingkungan.

Penulis memilih sampel penelitian dengan menggunakan teknik Cluster Sampling (Area
Sampling) dan Stratified Random Sampling. Teknik Area Sampling (daerah) digunakan untuk menentukan sampel bila obyek yang akan diteliti atau sumber data sangat luas. Obyek penelitian yang ingin diteliti melalui teknik ini berstrata (tidak sama) dengan jumlah yang cukup besar. Dalam penelitian ini, Paroki St. Petrus dan Paulus memiliki 25 lingkungan. Berhadapan dengan keterbatasan tenaga, maka penulis mengambil sampel 12 lingkungan di 6 wilayah berbeda. Masing-masing lingkungan dipilih 10-15 responden sebagai sampel penelitian.

\subsection{Analisa Penelitian}

Hasil penelitian tentang jati diri Kristiani yang dibangun melalui semangat untuk menumbuhkan persaudaraan menunjukkan situasi yang guyub antar umat di lingkungan. Hasil penelitian menunjukkan secara umum lingkungan telah mengushakan berbagai cara agar umat di lingkungan-lingkungan membangun paguyuban dengan semua anggota. Hal ini terbukti dengan ada banyak usaha yang mendorong persaudaraan antar anggota lingkungan melalui kegiatan rohani (misa lingkungan) dan sosial (mengunjungi orang sakit). Dari kedua bentuk tersebut umat lingkungan mendapat manfaat bagi tumbuhnya persaudaraan. Hasil menggembirakan dari penelitian yakni semakin banyak umat di lingkungan yang terlibat juga dalam karya-karya kasih. Bentuk perhatian tersebut yakni mengunjungi orang sakit, perhatian pada yang miskin dan bentuk-bentuk lainnya.

Kedua, hasil penelitian tentang persekutuan iman dan cinta kasih menunjukkan bahwa sebagian besar umat di lingkungan telah saling mengenal. Dalam hal ini kegiatan-kegiatan yang diadakan di lingkungan semakin menambah inspirasi bagi mereka untuk mengembangkan persaudaraan antar mereka. Tantangan yang dihadapi oleh lingkungan yakni ketidakhadiran umat lingkungan dengan berbagai alasan pribadi dan tuntutan kerja. Sebenarnya tantangan tersebut dapat diatasi dengan hasil penelitian yang menunjukkan kinerja pengurus lingkungan yang telah berjalan baik. Selain itu, usaha lain yang dapat dilakukan dengan mengoptimalkan kelompok-kelompok lain yang ada di lingkugan (OMK, PIA, WK, dll). Hasil penelitian telah menunjukkan perhatian lingkungan bagi kelompok-kelompok tersebut. Hal cukup menggembirakan dari hasil penelitian yakni umat lingkungan amat antusias membangun paguyuban cinta kasih dengan semua warga masyarakat.

Ketiga, hasil penelitian tentang pewartaan Kristiani menunjukkan bahwa belum ada pewar- 
taan iman melalui rekoleksi lingkungan. Namun hasil yang cukup menggembirakan yakni imam amat mendukung usaha pewartaan dalam lingkungan melalui berbagai cara. Salah satu bentuknya yakni kunjungan ke lingkungan dan keluarga. Selain itu, prodiakon dan petugas lain amat membantu karya pewartaan di lingkunganlingkungan. Muncul kemudian tantangan dari lingkungan untuk mengembangkan pengetahuan dan ketrampilan prodiakon agar semakin baik dalam karya pewartaan. Hasil penelitian dari mutu pewartaan menunjukkan bahwa semakin besar pewartaan yang dikemas secara menarik memberi inspirasi yang baik bagi hidup umat beriman.

Keempat, hasil penelitian tentan kehidupan beragama menunjukkan hasil menggembirakan bahwa telah ada kebiasaan mengadakan kegiatan bersama di masyarakat dan umat di lingkungan terlibat aktif dalam kegiatan tersebut (lebih dari 75\%). Selain itu, kebiasan berkunjung di hari raya agama menjadi sarana efekti bagi lingkungan untuk membangun kehidupan bersama dengan umat beragama lain. Hasil penelitian menunjukkan sebagian besar umat lingkungan mengunjungi sesama yang merayakan hari raya agama karena ingin membangun persaudaraan dan menumbuhkan sikap toleransi. Bahkan hasil penelitian juga menunjukkan adanya kerja sama umat lingkungan dengan sesama beragama lain melalui berbagai kegiatan.

Kelima, hasil penelitian tentang partisipasi membangun masyarakat menunjukkan bahwa lingkungan telah mengusahakan berbagai cara baik secara pribadi maupun bersama untuk mengembangkan masyarakat. Lingkungan mengadakan pelayanan kesehatan, pendidikan dan karya sosial yang ditujukan tidak hanya bagi orang Katolik saja namun bagi semua orang. Melalui berbagai usaha ini, ditemukan hasil penelitian bahwa karya ini dilakukan tanpa pilih kasih serta sebagai sarana pewartaan. Bahkan hasil penelitian menunjukkan umat lingkungan yang terlibat dalam kepengurusan RT/RW memberi diri bagi perkembangan masyarakat.

Selanjutnya, lingkungan-lingkungan memiliki tugas melaksanakan kebijakan-kebijakan dasar dari keuskupan dengan melihat hasil penelitian di atas.

a. Lingkungan tetap berusaha mengembangkan berbagai kegiatan pendalaman iman sebagai upaya untuk menumbuhkan jati diri Kristiani. Suasana yang kurang kondusif dan keaktifan umat lingkungan masih kecil dalam mengembangkan jati diri diri
Kristiani melalui kegiatan-kegiatan pendalaman iman.

b. Tantangan bagi pewartaan Kristiani di lingkungan-lingkungan masih terfokus pada petugas (pewarta). Sementara semestinya setiap orang dipanggil dengan cara mereka masing-masing untuk terlibat dalam karya pewartaan Kristiani.

c. Usaha mewujudkan kebijakan-kebijakan dasar tentang pastoral lingkungan masih mesti terus menerus diperkenalkan kepada umat agar umat semakin terlibat dalam tugas dan peran mereka masing-masing dalam lingkungan.

\section{KESIMPULAN DAN SARAN PASTORAL}

\subsection{Kesimpulan}

Hasil penelitian tentang pelaksanaan Kebijakan Dasar tentang Pastoral Ligkungan (KDPL) dalam lingkungan-lingkungan di Paroki St. Petrus dan Paulus Babadan bertitik tolak pada lima dimensi yang mendasari kehidupan umat beriman di lingkungan. Lima dimensi tersebut meliputi Jati Diri Kristiani, Persekutuan Iman dan Cinta Kasih, Pewartaan Kristiani, Kehidupan Beragama dan Partisipasi dalam Pembangunan Masyarakat. Dari dimensi-dimensi tersebut, ditemukan beberapa hal yang telah diusahakan oleh Dewan Paroki dan pengurus lingkungan, antara lain :

1. Pada bidang jati diri Kristiani, pengurus lingkungan telah mengusahakan kegiatankegiatan internal yang bertujuan untuk menumbuhkan pengetahuan iman Kristiani (BKSN, APP, Advent, Rosario) dan kegiatan-kegiatan tersebut dilaksanakan sesuai dengan situasi lingkungan masingmasing. Sementara kegiatan eksternal untuk mengembangkan jati diri Kristiani berupa kunjungan dan perhatian bagi orang-orang yang sakit dan miskin. Perhatian tersebut diwujudkan dalam bentuk uang dan barang baik baik warga katolik maupun masyarakat.

2. Dalam bidang persekutuan iman dan cinta kasih tampak bahwa persaudaraan di lingkungan-lingkungan telah terbangun baik dan hal ini didukung oleh pengurus lingkungan telah melaksanakan tugasnya dengan baik. Selain itu, lingkungan telah memberi kesempatan bagi tumbuhnya kelompok-kelompok lain dalam lingkungan. Keberadaan kelompok-kelompok ini diharapkan menjadi sarana tumbuhnya persau- 
daraan dan perkembangan iman serta cinta kasih umat beriman.

3. Pada bidang pewartaan Kristiani tampak bahwa lingkungan-lingkungan telah mengusahakan pewartaan bagi kelompok-kelompok oleh prodiakon (awam). Dari hasil penelitian dapat diketahui bahwa karya pewartaan selama ini telah memberi manfaat dan inspirasi bagi umat beriman di lingkungan.

4. Pada bidang kehidupan beragama, umat beriman terlibat dalam kegiatan bersifat rohani dan tradisi. Bahkan tingkat keterlibatan umat lingkungan cukup tinggi terutama di lingkungan yang jauh. Persaudaraan antar umat beriman ditunjukkan dalam tradisi saling berkunjung pada hari raya agama. Selain itu, usaha ini diwujudkan dalam kerja sama dalam bidang-bidang sosial dalam masyarakat baik bersifat keagamaan (syawalan) dan kerja bakti lingkungan (HUT RI).

5. Pada bidang partisipasi dalam pembangunan masyarakat tampak bahwa lingkunganlingkungan telah mengusahakan pelayanan di bidang kesehatan, pendidikan, sosial kemasyarakatan, dan keterlibatan RT/RW. Umat lingkungan-lingkungan memiliki kepedulian besar untuk mengusahakan kebaikan bersama.

Dengan memperhatikan usaha-usaha yang telah dilakukan lingkungan di atas, terdapat beberapa tantangan bagi lingkungan mengembangkan kehidupan umat beriman.

a. Lingkungan telah mengusahakan berbagai bentuk kegiatan pendalaman iman untuk menanamkan jati diri Kristiani. Namun, tingkat keterlibatan umat lingkungan dalam kegiatan-kegiatan pendalaman iman tersebut masih belum maksimal. Hal ini dapat dilihat dari tingkat kehadiran pribadi dan bentuk keterlibatan mereka dalam kegiatankegiatan tersebut. Tantangan selanjutnya yakni bagaimana usaha yang telah dilakukan lingkungan tak hanya memberi manfaat personal namun juga membawa manfaat sosial.

b. Dalam mengembangkan kesatuan iman dan cinta kasih, ditemukan hambatan-hambatan umat lingkungan untuk bersekutu sebagai satu kesatuan iman. Masing-masing lingkungan memiliki dinamika dan tantangan yang berbeda. Selain itu, kinerja pengurus lingkungan yang telah berjalan baik saat ini perlu mengembangkan kembali kelompok-kelompok yang ada dalam lingkungan sebagai sarana mengembangkan iman umat beriman. Sementara tantangan ekternal lingkungan berupa masih kurangnya keterlibatan umat lingkungan dalam berbagai kegiatan di masyarakat sebagai upaya membangun paguyuban hidup bersama.

c. Tantangan pewartaan Kristiani bagi lingkungan yakni mengusahakan rekoleksi di lingkungan-lingkungan sebagai sarana mengembangkan iman umat beriman. Selain itu, petugas-petugas yang telah ada masih perlu mendapatkan pembekalan berupa ketrampilan dan wawasan dalam melayani umat di lingkungan-lingkungan.

d. Tantangan dalam kehidupan beragama umat lingkungan yakni perlunya mengembangkan bentuk-bentuk kerjasama tidak hanya terbatas pada kegiatan-kegiatan doa rutin, namun melalui berbagai kegiatan bersama masyarakat.

e. Tantangan dalam partisipasi pembangunan masyarakat adalah menumbuhkan semangat pelayanan yang ditujukan bagi semua orang. Pelayanan yang dilakukan demi pembangunan masyarakat mesti didorong semangat kasih yang tanpa membedabedakan.

\subsection{Saran}

Berdasarkan beberapa tantangan dari hasil penelitian tersebut, maka diusulkan beberapa saran pastoral yang dapat diusahakan bagi pengurus lingkungan dan tim pastoral paguyuban Paroki St. Petrus dan Paulus Babadan. Beberapa usulan berikut terkait dengan usaha pengurus lingkungan mengembang umat beriman di tingkat lingkungan sesuai dengan tuntunan Kebijakan Dasar tentang Pastoral Lingkungan yakni :

a. Pengurus lingkungan-lingkungan mengembangkan pemahaman yang mendalam tentang lima bidang pokok yang termuat dalam Kebijakan Dasar tentang Pastoral Lingkungan Keuskupan Agung Semarang.

b. Tim pewartaan paroki dan pengurus lingkungan menentukan waktu, tempat materi pertemuan yang sesuai dengan dinamika kehidupan umat di lingkungan. Dengan harapan bahwa semakin banyak umat di lingkungan yang terlibat di tengah kesibukan mereka.

c. Dalam bidang persekutuan iman dan cinta kasih, pengurus lingkungan menyusun sebuah kegiatan yang rekreatif-formal. 
Kegiatan ini dapat menumbuhkan persaudaraan yang telah ada melalui kegiatan yang mendorong masing-masing anggota lingkungan untuk terlibat.

d. Pengurus lingkungan dan tim pewartaan mengadakan rekoleksi bersama lingkunganlingkungan dengan melibatkan komunitas biarawan-biarawati sebagai pemandu. Selain itu, perlu pembekalan prodiakon dan petugas lain dengan melibatkan mereka dalam pembekalan baik di paroki maupun melalui seminar-seminar. Wawasan dan ketrampilan perlu mendapat dukungan berupa sarana pelatihan terutama kelompokkelompok yang sudah ada di lingkungan (OMK, PIA, PIR, WK, dll).

e. Pastor Paroki sebagai pemegang tanggungjawab memberi kesempatan umat lingkungan untuk terlibat aktif dalam bidang kerja sama lintas agama dan kelompok masyarakat. Pastor paroki dan tim pewartaan membekali umat dengan pemahaman dialog antar agama seperti yang termuat dalam dokumen-dokumen Gereja.

f. Bagi pengurus lingkungan dan bidang pelayanan kemasyarakatan paroki, usaha untuk mengembangkan keterlibatan umat lingkungan dapat dilakukan dengan membentuk tim kerja yang mampu terlibat dalam keprihatinan dan ketidakadilan yang terjadi di lingkungan-lingkungan. Pengurus lingkungan dan bidang pelayanan kemasyarakatan dapat bekerja sama dengan semua pihak.

\section{Andreas Budiyo}

Pengajar di SMP Yayasan Yos Sudarso, Metro, Lampung, Sumatera Selatan.

Email: buddyragil@yahoo.com

\section{CATATAN AKHIR}

1 Gaudium et Spes 6 "Pola masyarakat industri lambat laun makin menyebar, mengantar berbagai bangsa kepada kekayaan ekonomi, serta secara mendalam mengubah pengertian-pengertian dan kondisi-kondisi hidup kemasyarakatan yang dulu bertahan berabad-abad lamanya."

2 Bdk. Lumen Gentium 5.

3 M. Nur Widi, Pr, Eklesiologi ARDAS Keuskupan Agung Semarang, Kanisius 2009, vi.

4 Dua ciri khas ini menjadi ciri pokok untuk menunjukkan ciri khas dari penelitian ini. Penjelasan lebih lanjut dibahas oleh Ida Bagoes Mantra dalam Langkah-langkah Penelitian survei, Usulan Penelitian dan Laporan Penelitian. BPFGUGM: Yogyakarta, 2001, 1-2.
5 James O’Halloran., Signs of Hope: Developing Small Christian Communities, Columbia Press, USA 1991.

6 James O'Halloran., Signs of Hope: Developing Small Christian Communities, 22.

7 Lingkungan digunakan di Keuskupan Agung Semarang untuk menunjukkan paguyuban orangorang yang terdiri dari 10-50 kepala keluarga dan tinggal berdekatan (bdk Keuskupan Agung Semarang, Pedoman Dasar Dewan Paroki Keuskupan Agung Semarang 2004 dan Penjelasannya, Bab I, psl 1, Semarang 2004, 1114).

8 A. Margana., Komunitas Basis : Gerak Menggereja Kontekstual, 46.

9 Jose Marins - Teolide M. Trevisan., Base Ecclesial Communities, Claretian Publications, Pilipina 2002, 2-3.

10 A. Margana., Komunitas Basis : Gerak Menggereja Kontekstual, Kanisius, Yogyakarta 2004, 12.

11 A. Margana, Komunitas Basis : Gerak Menggereja Kontekstual, 13.

12 James O’Halloran dalam Signs of Hope: Developing Small Christian Communities, 7.

13 Sinode Para Uskup., Doctrine and Life, Dominican Publications, Dublin Januari 1986, 47.

14 JB.Mardikartono, SJ., Pengembangan Jemaat : Paroki Sepanjang Masa, Seri Pastoral 152, Pusat Pastoral Yogyakarta 1989, 32.

15 James O’Halloran, Sign of Hope: Developing Small Christian Communities, 5.

16 Leonardo Boff., Ecclesiogenesis : The Base Communities Reinvent The Church, Maryknoll, New York 1986.

17 Leonardo Boff., Ecclesiogenesis: The Base Communities Reinvent the Church, 3.

18 James O'Halloran, Sign of Hope: Developing Small Christian Communities,7.

19 Paus Pius VI menegaskan peran ini dalam Evangelii Nuntiandi (Evangelization Today), Dublin: Dominican Publications, 1997, no 58, 31.

20 Alois Maveneka., A Church Self-Reliant and Missionary, 90.

21 James O'Halloran, Sign of Hope: Developing Small Christian Communities, 6-7. Data ini diambil dari survei terakhir pada tahun 1990.

22 Departemen Dokumentasi dan Penerangan KWI, Dokumen Sidang-sidang Federasi Konferensikonferensi Para Uskup Asia, Seri Dokumen FABC no 1, V, Mardi Yuana, Bogor 1995, 249.

23 Departemen Dokumentasi dan Penerangan KWI, Dokumen Sidang-sidang Federasi Konferensikonferensi Para Uskup Asia, 250.

24 Departemen Dokumentasi dan Penerangan KWI, Dokumen Sidang-sidang Federasi Konferensikonferensi Para Uskup Asia, 250-251.

25 A. Ernout, A. Meillet, Dictionnarie Etymologique de la langue Latine. Dalam Yves Lacoste (Ed), Encyclopedia of Christian Theology., 342. 
Dalam penjelasan Lumen Gentium 7 tentang Gereja sebagai Tubuh Mistik Kristus yang disatukan oleh karena masing-masing anggota menerima roti yang sama dan masing-masing menjadi anggota yang seorang terhadap yang lain ( Rom 12:5).

27 G. Kirchberger., Gereja Yesus Kristus Sakramen Roh Kudus, 134-135.

28 Bdk. Lumen Gentium 4.

29 James O’Halloran, Sign of Hope: Developing Small Christian Communities, 7.

30 James O’Halloran, Sign of Hope: Developing Small Christian Communities, 7-8. Gambaran ini berdasarkan situasi Gereja di Amerika Latin yang berkembang atas dukungan komunitas-komunitas kecil Kristiani di berbagai tempat dalam Gereja.

31 E. Martasudjita, Sakramen-Sakramen Gereja: Tinjaun Teologis, Liturgis, dan Pastoral. Kanisius, Yogyakarta, 2003, 107.

32 Dr. Huub J.W.M Boelaars, OFM., Indonesianisasi : Dari Gereja Katolik di Indonesia menjadi Gereja Katolik Indonesia, Kanisius 2005, 342.

33 Dr. Huub J.W.M Boelaars, OFM., Indonesianisasi : Dari Gereja Katolik di Indonesia menjadi Gereja Katolik Indonesia, 344.

34 Dr. Huub J.W.M Boelaars, OFM., Indonesianisasi : Dari Gereja Katolik di Indonesia menjadi Gereja Katolik Indonesia, 342-343.

35 lih. G.Budi Subanar.,Soegija: Si Anak Betlehem van Java, Kanisius, Yogyakarta 2003,102-103.

36 lih. Penjelasan J. Dijkstra SJ, Mgr. A.Soegijapranata SJ Penganjur Linkungan, dalam KAS, Buku Kenangan : Peringatan 25 tahun Wafat Mgr.Albertus Soegijapranata SJ, KAS: Semarang 1998, 13-14.

37 Tujuan ini dijelaskan pada bagian latar belakang perumusan Kebijakan Dasar KAS tentang Pastoral Lingkungan. Gereja Keuskupan Agung Semarang ingin menegaskan peran penting lingkungan dalam mengembang panggilan memberi kesaksian di tengah masyarakat (Keuskupan Agung Semarang, Kebijakan-kebijakan Dasar Keuskupan Agung Semarang tentang Pastoral Lingkungan, P3J KAS, tanpa penerbit, 1991, I.B, 2.2,2, 1)

38 Keuskupan Agung Semarang, Kebijakan-kebijakan Dasar Keuskupan Agung Semarang tentang Pastoral Lingkungan, I, 1.3, 2.

39 Keuskupan Agung Semarang, Kebijakan-kebijakan Dasar Keuskupan Agung Semarang tentang Pastoral Lingkungan, II, 2.1, 4, 3.

40 Dewan Karya Pastoral Keuskupan Agung Semarang., Nota Pastoral tentang Arah Dasar Umat Allah 2011-2015, 5.

41 Robert Hardawiryana, SJ., Cara Baru Menggereja di Indonesia 5, 103.

42 Robert Hardawiryana, SJ., Cara Baru Menggereja di Indonesia 5, 105.

43 Keuskupan Agung Semarang, Kebijakan-kebijakan Dasar Keuskupan Agung Semarang tentang Pastoral Lingkungan, 2.3, hal 4.
44 Keuskupan Agung Semarang, Kebijakan-kebijakan Dasar Keuskupan Agung Semarang tentang Pastoral Lingkungan, 2.4, 1 hal 4.

45 bdk. Lothar Schreiner, Adat und Evangelium, Heidelberg 1969 (desertasi) terjemahan : Telah Kudengar dari Ayahku: Perjumpaan adat dengan Iman Kristen di Tanah Batak, Gunung Mulia, Jakarta 1978, 1.

46 Robert Hardawiryana, SJ., Cara Baru Menggereja di Indonesia 5,126.

47 Keuskupan Agung Semarang, Kebijakan-kebijakan Dasar Keuskupan Agung Semarang tentang Pastoral Lingkungan, II. 2.4, 5.

48 Ibid KDPL, II, 2.5, 3, 5.

49 Keuskupan Agung Semarang, Kebijakan-kebijakan Dasar Keuskupan Agung Semarang tentang Pastoral Lingkungan, 2.5, 4, 5.

50 Data diambil dari Data Statistik Paroki St. Babadan tgl 31 Desember 2012.

51 Hasil wawancara dengan Koordinator Ketua Lingkungan paroki pada tanggal 29 Oktober 2013.

\section{DAFTAR RUJUKAN}

\section{Buku Pendukung}

Bambang Sutrisno, D., 1999, Lingkungan : Sebuah Permenungan. P3J KAS Semarang.

Boff, L.,1986 Ecclesiogenesis : The Base Communities Reinvent The Church, Maryknoll, New York.

Boelaars, J.W.M., 2005, Indonesianisasi, Dari Gereja katolik Indonesia menjadi Gereja Katolik Indonesia, Kanisius, Yogyakarta.

Budi Purnomo, A., 1999, Membangun Jemaat yang Hidup dalam Roh Kudus, Kanisius, Yogyakarta.

Clark, B., 1988, Pemimpin Lingkungan (Pastoral Leadership :Building Christian Communities), Seri Pastoral 143, Yogyakarta.

Congar, Y., 1983, I Believe in the Holy Spirit Vol II, The Seabury Press, New York.

Dijkstra, J.,1988, "Mgr. A.. Soegijapranata SJ Penganjur Lingkungan”,, dalam Buku Kenangan: Peringatan 25 tahun Wafat Mgr. Albertus Soegijapranata SJ, KAS, Semarang.

Fuellenbach, J.,2004, Church Community for the Kingdom, St. Cruz, Logos Publication, Manila.

Gitowiratmo, St., \& Francis Purwanto., 2007, Seputar Dewan Paroki, Kanisius, Yogyakarta. 
Hooijdonk, P. van., 1990, Pengembangan Jemaat : Kepemimpinan Pastoral, Seri Pastoral 100, Pusat Pastoral Yogyakarta, Yogyakarta.

K. Wood, Susan., 2000, Lex Orandi: Sacramental Orders, The Liturgical Press, Minnesota, USA.

Kress, Robert., 1985, The Church: Communion, Sacrament, Communicatio. Paulist Press, New York.

Krispurwana Cahyadi,T.,2009, Pastoral Gereja: Paroki dalam Upaya Membangun Gereja yang Hidup, Kanisius Yogyakarta.

Mardikartono, JB., 1989Pengembangan Jemaat : Paroki Sepanjang Masa, Seri Pastoral 152, Pusat Pastoral Yogyakarta.

Margana, A., $2004 \quad$ Komunitas Basis, Gereja Menggereja Kontekstual, KKA dan Kanisius, Yogyakarta.

Marins, Jose. \& Teolide M. Trevisan, 2002 Base Ecclesial Communities, Claretian Publications, Pilipina.

Martasudjita, E., 2003 Sakramen-Sakramen Gereja: Tinjaun Teologis, Liturgis, dan Pastoral. Kanisius, Yogyakarta.

Mulder, A., 1984, De Missie in Tropisch Nederland (Misi di Negeri Belanda Tropis), Den Haag.

Nur Widi,M., 2009 Eklesiologi ARDAS Keuskupan Agung Semarang, Kanisius.

O’Halloran, James., 1991 Signs of Hope: Developing Small Christian Communities, The Columbia Press, New York.
Ray, David R., 2009 Gereja yang Hidup : Ideide segar menjadikan Ibadah lebih Indah., BPK Gunung Mulia, Jakarta.

Widyahadi Seputra, A.,(dkk), 1999 Hidup

dalam Persaudaraan Sejati, CV Celestu Hieronika dan Komisi PSE KAJ, Jakarta.

\section{Artikel}

Komisi Kateketik KWI.,1993, Membina Iman yang Terlibat dalam Masyarakat, dalam Pertemuan Kateketik Keuskupan seIndonesia (PKKI V), Komisi Kateketik KWI, Obor, Jakarta.

Schreiner, Lothar.,1979, Adat und Evangelium, diterjemahkan oleh Heidelberg Telah Kudengar dari Ayahku : Perjumpaan adat dengan Iman Kristen di Tanah Batak, Gunung Mulia, Jakarta

Shorter.,1973, “The Future of the Catechist in Afrika” dalam World Mission, vol 24 no 3.

Van Hooijdonk., P.,1990, Pengembangan Jemaat: Kepemimpinan Pastoral, dalam Seri Pastoral 100, Pusat Pastoral Yogyakarta.

Yohanes Paulus II.,1995, Post-synodal Apostoliz Axhortation Ecclesia in Asia : FABC Papers no.94, 32. 1992, Intruksi “Dialog dan Proklamasi; Pemikiran-pemikiran dan Perspektifperspektif (19 Mei 1991), diterjemahkan oleh Panitia Kepausan untuk Dialog Antarumat beragama dan Kongregasi untuk Evangelisasi para bangsa. 